Vol. 1 No. 3 Juli 2021 e-ISSN : 2774-6283 | p-ISSN : 2775-0019

\title{
PENERAPAN BIBLIOCOUNSELING UNTUK MENINGKATKAN RESILIENSI DIRI (SELF RESILIENCE) PESERTA DIDIK DI MASA PEMBELAJARAN DARING
}

\author{
DWI RAHMAWATI \\ SMK Negeri 1 Pemalang \\ E-mail: Dwirahmawatitr212@gmail.com
}

\begin{abstract}
ABSTRAK
Tujuan penelitian ini yaitu untuk meningkatkan resiliensi diri peserta didik dimasa pembelajaran daring dengan layanan konseling kelompok dengan teknik bibliocounseling. Jenis dan pendekatan dalam penelitian ini adalah metode penelitian quasi experimen dengan desain non-equivalent pretest-posttest control group. Hasil penelitian menunjukkan bahwa model bimbingan kelompok dengan teknik bibliocounseling dapat meningkatkan resiliensi terutama pada aspek efikasi diri, penilaian realistis terhadap lingkungan, problem solving Peserta Didik SMK Negeri 1 Pemalang.
\end{abstract}

Kata Kunci : Resiliensi, bibliocounseling, distance learning

\section{PENDAHULUAN}

Pandemi covid 19 tidak hanya berpengaruh pada ekonomi secara global tetapi dunia pendidikan pun terkena dampaknya. Untuk mengurangi penyebaran virus klaster sekolah maka pelaksanaan pembelajaran secara daring dilaksanakan karena aturan protokoler kesehatan dengan melarang adanya kerumunan massa sekolah. Dengan adanya pandemi covid 19 membuat warga sekolah dari Kepala sekolah, Tenaga Pendidik, Tenaga Kependidikan dan Peserta Didik memulai kebiasaan baru dalam menghadapi pembelajaran moda daring. Dirubahnya sistem pembelajaran dari tatap muka menjadi pembelajaran moda daring atau distance learning (Pembelajaran Jarak Jauh) berakibat munculnya rasa kebosanan dan kemalasan peserta didik dengan alasan kurangnya fasilitas belajar, kebingungan dalam menyelesaikan tugas yang dianggap terus menerus dan memberatkan.

Banyaknya permasalahan dengan kebiasaan baru dalam pembelajaran menggunakan moda daring, khususnya yang dialami oleh Peserta Didik SMK Negeri 1 Pemalang. Peserta Didik merasa dengan sistem pembelajarn daring tidak seefektif pembelajaran tatap muka, mereka tidak bisa fokus dan sulit memahami pembelajaran. Ditambah dengan adanya permasalahan teknis, seperti lemahnya jaringan internet dan terkadang guru hanya memberikan tugas tanpa menjelaskan materi terdahulu sehingga Peserta Didik tidak bisa memahami materi dan menyebabkan mereka kebingungan untuk menyelesaikan tugasnya, dari kebingungan tersebut memicu terjadinya stres karena merasa terlalu banyak tugas dan belum memehami materi pelajaran. Stres yang dialami Peserta Didik disebabkan monotonnya pembelajaran dan banyak tugas yang diberikan oleh guru menyebabkan Peserta Didik merasa jenuh, mudah capai, malas mengerjakan tugas dan lebih mudah mengalami stres

Mencermati fenomena yang ada pada Peserta Didik SMK Negeri 1 Pemalang Tahun Pelajaran 2020/2021 dan laporan beberapa guru mapel tentang menurunnya minat belajar, maka betapa pentingnya daya tahan (resiliensi) bagi peserta didik agar mampu menghadapi tantangan dalam pembelajaran, dan dapat terhindar dari perilaku negatif yang merugikan diri sendiri.

Istilah resiliensi diformulasikan pertama kali oleh Block (Klohnen, 1996) dengan nama ego-resilience, yang diartikan sebagai kemampuan umum yang melibatkan kemampuan penyesuaian diri yang tinggi dan luwes saat dihadapkan pada tekanan dari dalam maupun dari luar. Secara spesifik, egoresilience merupakan satu sumber kepribadian yang berfungsi membentuk konteks lingkungan jangka pendek maupun jangka panjang, di mana sumber daya tersebut memungkinkan individu untuk memodifikasi tingkat karakter dan cara mengekspresikan pengendalian ego yang biasa dilakukan individu. 
Resiliensi mempunyai pengertian sebagai suatu kemampuan untuk bangkit kembali (to bounce back) dari pengalaman emosi negatif dan kemampuan untuk beradaptasi secara fleksibel terhadap permintaan-permintaan yang terus berubah dari pengalaman pengalaman stres (Ong et al., 2006; Tugade \& Fredericson et al., 2003). Joseph (Isaacson, 2010) menyatakan resiliensi adalah kemampuan individu untuk menyesuaikan diri dan beradaptasi terhadap perubahan, tuntutan, dan kekecewaan yang muncul dalam kehidupan. Asumsi mendasar dalam studi mengenai resiliensi adalah bahwa beberapa individu tetap baikbaik saja meskipun telah mengalami situasi yang sarat adversitas dan beresiko, sementara beberapa individu lainnya gagal beradaptasi dan terperosok dalam adversitas atau resiko yang lebih berat lagi (Schoon, 2006).

Berdasarkan Challen, Machin, \& Gillham, (2014) resiliensi ini berperan dalam mempengaruhi Peserta Didik dalam mengurangi stres dan kecemasan, hal ini dapat berpengaruh positif mempengaruhi kinerja akademis Peserta Didik dan kesejahteraan saat ini ataupun nanti di masa depan. Bisa dikatakan dengan memiliki resiliensi, Peserta Didik akan memiliki kemampuan yang dapat dijadikan fondasi dalam membangun karakter positif untuk bertahan dan mampu menghadapi tugasnya sebagai Peserta Didik ketika menghadapi pembelajaran dimasa pandemik covid-19.

Peserta didik cenderung mempunyai masalah resiliensi dalam bidang akademik maupun non akademik. Masalah ini tidak hanya terjadi pada peserta didik yang bermasalah tetapi peserta didik yang berprestasipun berpontensi mempunyai masalah resiliensi, maka dari itu Guru Bimbingan Konseling diharapkan mampu membantu setiap perserta didik dalam memecahkan resiliensi melalui konseling kelompok menggunakan keterampilan konseling yang dimiliki.

Tindakan nyata yang dapat dilakukan oleh Guru Bimbingan konseling dalam meningkatkan resiliensi Peserta Didik dengan melaksanakan layanan konseling. Alternatif layanan bimbingan konseling dengan jenis layanan kelompok dengan teknik bibliocounseling sebagai sarana layanan untuk mengurai masalah resiliensi peserta didik. Hasfera (2018) menyatakan bahwa bibliocounseling adalah dukungan psikoterapi melalui bahan bacaan untuk membantu seseorang yang mengalami permasalahan personal. Metode bibliocounseling dapat digunakan untuk membantu konseli yang mengalami kesulitan untuk mengungkapkan permasalahan secara verbal.

Montgomery \& Maunders (2015) menunjukkan bahwa, bibliocounseling yang kreatif mampu memberikan efek positif terhadap perubahan perilaku internalisasi, eksternlisasi serta menguatkan perilaku prososial Peserta Didik. Bibliocounseling dapat mengembangkan kesejahteraan hidup Peserta Didik (Lucas \& Soares, 2013). Di lain sisi, Hariyadi (2014) melalui penelitiannya terkait penggunaan teknik biblioconseling, ditemukan bahwa biblioconseling efektif meningkatkan kemampuan Peserta Didik (self knowledge, self direction, dan self esteem).

Sholih, Rochani et al (2017) melakukan penelitian dengan tujuan meningkatkan resiliensi remaja melalui bibliocounseling. Penelitian ini dillakukan di Warga belajar PKBM Kencana Ungu. Hasil penelitian ini menunjukan bibliocounseling efektif dalam meningkatkan resiliensi remaja. Tutor di PKBM Kencana Ungu diharapkan dapat mengimplementasikan bibliocounseling dalam peningkatan resiliensi remaja.

Dari fenomena yang dialami oleh peserta didik SMK Negeri 1 Pemalang di masa pembelajaran daring dan beberapa shearing dengan guru mapel, Penelitian ini akan membahas teknik bibliocounseling sebagai salah satu teknik intervensi untuk meningkatkan resiliensi peserta didik di masa pembelajaran daring.

\section{METODE PENELITIAN}

Pendekatan penelitian yang digunakan adalah Pendekatan kuantitatif. Pendekatan kuantitatif sebagai pendekatan ilmiah didisain untuk menjawab pertanyaan penelitian atau hipotesis secara spesifik dengan penggunaan statistik dianggap relevan oleh peneliti sebagai 
pendekatan yang digunakan untuk mengetahui penerapan Teknik bibliocounseling untuk meningkatkan resiliensi Peserta Didik. Menurut Cresswell (2008:46) pendekatan kuantitatif merupakan jenis penelitian pendidikan dimana para peneliti memutuskan apa yang harus diteliti, memiliki pertanyaan yang lebih fokus, menganalisis data menggunakan analisis statistik, dan melakukan penyelidikan tersebut dengan cara yang objektif.

Metode yang digunakan dalam penelitian ini adalah Quasi Experimental. Quasi experimental mempunyai kelompok kontrol, tetapi tidak dapat berfungsi sepenuhnya untuk mengontrol variabel-variabel luar yang mempengaruhi pelaksanaan eksperimen (Sugiyono, 2012:114). Desain eksperimen yang digunakan adalah Nonequivalent Pretest-Posttest Control Group Design, yaitu desain penelitian yang dilaksanakan terhadap dua kelompok, yakni kelompok eksperimen dan kelompok kontrol.

Dalam desain Nonequivalent Pretest-Posttest Control Group, kelompok eksperimen maupun kelompok kontrol tidak dipilih secara random. Kelompok kontrol merupakan kelompok pembanding dan tidak diberikan perlakuan, sedangkan kelompok eksperimen diberikan perlakuan berupa teknik bibliocounseling. Kedua kelompok dikenakan pengukuran sebanyak dua kali sebelum dan sesudah diberikan perlakuan (Sugiyono, 2012:116). Data pretest-posttest diambil melalui instumen untuk mengungkap tingkat resiliensi Peserta Didik. Skema model penelitian quasi eksperimental dengan desain Nonequivalent Pretest-Posttest Control Group, sebagai berikut.

\begin{tabular}{|lll|}
\hline $\mathrm{O}_{1}$ & $\mathrm{x}$ & $\mathrm{O}_{2}$ \\
\hline $\mathrm{O}_{3}$ & $\mathrm{x}$ & $\mathrm{O}_{4}$ \\
\hline
\end{tabular}

(Campbell \& Stanley, 1963:47)

Lokasi penelitian ini dilaksanakan di SMK Negeri 1 Pemalang yang berlokasi di Jl. Jend Gatot Subroto No. 31 Pemalang. Dalam penelitian ini populasi penelitiannya adalah Peserta Didik kelas XI. TKJ 1 dan 2 SMK Negeri 1 Pemalang yang secara administratif terdaftar dan aktif dalam pembelajaran yang berjumlah 72 orang Peserta Didik. Pengambilan sampel dalam penelitian ini menggunakan teknik purposive sampling (sampel bertujuan).

Sampel dalam penelitian ini adalah Peserta Didik kelas XI. TKJ 1 dan 2 SMK Negeri 1 Pemalang. Hal ini mengacu pada pendapat Schoon (2006:9) bahwa setiap individu memiliki kapasitas resiliensi yang berbeda antara satu dengan yang lainnya, semakin tinggi kapasitas resiliensi individu maka semakin baik ketahanan dalam menghadapi masalah sehingga terhindar dari perilaku-perilaku yang merugikan bagi kehidupannya. Dengan demikian secara umum Peserta Didik kelas XI. TKJ 1 dan 2 SMK Negeri 1 Pemalang yang telah teridentifikasi tingkat resiliensinya berdasarkan pretest instrumen resiliensi menjadi sampel penelitian. Sehingga peneliti mengambil kelas XI. TKJ. 1 sebagai kelas eksperimen yang akan diberikan perlakuan berupa teknik bibliocounseling dan kelas XI. TKJ.2 sebagai kelas kontrol yang berperan sebagai kelompok pembanding yang tidak diberikan perlakuan.

Analisis uji validitas instrumen dilakukan dengan menggunakan program SPSS 19. Reliabilitas dinyatakan oleh koefesien yang angkanya berkisar antara 0 sampai dengan 1,00. Semakin tinggi koefesien reliabilitas mendekati 1,00 semakin tinggi reliabilitasnya. Proses penghitungan reliabilitas instrumen penelitian dilakukan dengan menggunakan bantuan komputer dengan program SPSS 19.

\section{HASIL DAN PEMBAHASAN}

\section{Hasil}

Keseluruhan populasi penelitian (72 Peserta Didik) ditetapkan sebagai sampel penelitian. Data mengenai profil resiliensi Peserta Didik diperoleh dari hasil penyebaran instrumen skala resiliensi Peserta Didik terhadap sampel penelitian. Dari data yang terkumpul, diperoleh profil resiliensi Peserta Didik dan gambaran aspek resiliensi Peserta Didik. Hasil pengumpulan data tersebut kemudian diolah dan dijadikan bahan pertimbangan untuk menerapkan teknik bibliocounseling untuk meningkatkan resiliensi Peserta Didik. 
Data penelitian menunjukkan bahwa profil resiliensi Peserta Didik yakni sebesar 11,11 \% dari keseluruhan Peserta Didik yang menjadi sampel penelitian memiliki resiliensi pada tingkatan tinggi atau berada pada kategori resilien, 62,5\% memiliki resiliensi pada tingkatan sedang atau berada pada kategori cukup resilien, dan 26,39 \% memiliki resiliensi pada tingkatan rendah atau berada pada kategori kurang resilien. Secara lebih rinci profil resiliensi Peserta Didik disajikan pada tabel 1.

Tabel 1. Profil umum resiliensi Peserta Didik SMK Negeri 1 Pemalang

\begin{tabular}{|l|l|c|c|}
\hline \multicolumn{1}{|c|}{ Tingkatan } & \multicolumn{1}{c|}{ Kategori } & Frekuensi & Persentase \\
\hline Tinggi & Resilien & 8 & $11,11 \%$ \\
\hline Sedang & Cukup Resilien & 45 & $62,5 \%$ \\
\hline Rendah & Kurang Resilien & 19 & $26,39 \%$ \\
\hline
\end{tabular}

Setelah dilakukan layanan konseling kelompok dengan teknik bibliocounseling dapat dilihat perubahan data antara perbandingan data pretes dan data postes kelas eksperimen sebagai kelas yang diberi perlakuan dan kelas kontrol yang tidak diberikan perlakuan. Penyajian pada bagian ini merupakan jawaban atas pertanyaan penelitian yang ketiga yakni perubahan data resiliensi antara pretes dan postes. Berikut ini disajikan data resiliensi Peserta Didik hasil perbandingan pretes dan postes kelas kontrol dan eksperimen.

\section{Perubahan Data Resiliensi Peserta Didik Kelas Kontrol}

Data Peserta Didik pada kelas kontrol sedikit mengalami perubahan resiliensi. Perubahan data resiliensi Peserta Didik kelas kontrol antara pretes dan postes tersaji pada tabel 2.

Tabel 2. Perbandingan Data Resiliensi Pretes dan Postes Peserta Didik Kelas Kontrol

\begin{tabular}{|l|c|c|c|c|}
\hline \multirow{2}{*}{ Tingkatan } & \multicolumn{2}{c|}{ Pretest } & \multicolumn{2}{c|}{ Postest } \\
\cline { 2 - 5 } Tinggi & Frekuensi & Persentase & Frekuensi & Persentase \\
\hline Sedang & 5 & $13,89 \%$ & 4 & $16,67 \%$ \\
\hline Rendah & 22 & $61,11 \%$ & 22 & $61,11 \%$ \\
\hline
\end{tabular}

Dari data tersebut dapat disimpulkan terdapat perubahan data resiliensi kelas kontrol pretes dan postes pada kategori tinggi mengalami penurunan persentasi, sedangkan pada kategori sedang mengalami kenaikan persentasi, dan pada kategorti rendah kembali mengalami penurunan. Selain dikaji perubahan berdasarkan kategori tingkat resiliensi, dikaji pula tingkat ketercapaian resiliensi yang dimiliki Peserta Didik SMK Negeri 1 Pemalang. Adapun data perbandingan tingkat ketercapaian resiliensi Peserta Didik tersaji pada tabel 3.

Tabel 3. Perbandingan Data Tingkat Ketercapaian Resiliensi Pretes dan Postes Peserta Didik Kelas Kontrol

\begin{tabular}{|c|c|c|}
\hline Ketercapaian & Pretes Kelas Kontrol & $\begin{array}{c}\text { Posttes Kelas } \\
\text { Kontrol }\end{array}$ \\
\hline Tingkat Ketercapaian (\%) & 39,79 & 37,09 \\
\hline
\end{tabular}




\section{Perubahan Data Resiliensi Peserta Didik Kelas Eksperimen}

Perubahan data resiliensi Peserta Didik pada kelas eksperimen setelah dilakukan layanan bimbingan kelompok teknik bibliocounseling. Perubahan data antara pretes dan postes tersaji pada tabel 4 .

Tabel 4. Perbandingan Data Resiliensi Pretes dan Postes Peserta Didik Kelas Eksperimen

\begin{tabular}{|l|c|c|c|c|}
\hline \multirow{2}{*}{ Tingkatan } & \multicolumn{2}{c|}{ Pretest } & \multicolumn{2}{c|}{ Postest } \\
\cline { 2 - 5 } Tinggi & Frekuensi & Persentase & Frekuensi & Persentase \\
\hline Sedang & 3 & $8,33 \%$ & 6 & $16,67 \%$ \\
\hline Rendah & 23 & $63,89 \%$ & 25 & $69,44 \%$ \\
\hline
\end{tabular}

Dari data tersebut dapat disimpulkan terdapat perubahan data resiliensi kelas eksperimen pretes dan postes pada kategori tinggi mengalami kenaikan persentasi, begitu pula pada kategori sedang mengalami kenaikan persentasi, sedangkan pada kategorti rendah mengalami penurunan. Selain dikaji perubahan berdasarkan kategori tingkat resiliensi, dikaji pula tingkat ketercapaian resiliensi kelas eksperimen yang dimiliki Peserta Didik SMK Negeri 1 Pemalang. Adapun data perbandingan tingkat ketercapaian resiliensi Peserta Didik tersaji pada tabel 5.

Tabel 5. Perbandingan Data Tingkat Ketercapaian Resiliensi Pretes dan Postes Peserta Didik Kelas Eksperimen

\begin{tabular}{|c|c|c|}
\hline Ketercapaian & Pretes Kelas Kontrol & $\begin{array}{c}\text { Posttes Kelas } \\
\text { Kontrol }\end{array}$ \\
\hline Tingkat Ketercapaian (\%) & 34,35 & 38,73 \\
\hline
\end{tabular}

\section{Hasil Uji Efektivitas Menggunakan Prosedur Statistik}

Uji efektivitas self-instruction training untuk meningkatkan resiliensi Peserta Didik dimulai dengan uji normalitas dan homogenitas. Jika data berdistribusi normal maka selanjutnya akan menguji homogenitas variansinya, dan uji $\mathrm{T}$, namun jika data tidak berdistribusi normal maka akan digunakan uji Mann Whitney.

\section{a. Uji Normalitas}

Uji normalitas digunakan untuk mengetahui apakah data yang diperoleh berdistribusi normal atau tidak. Pengujian normalitas data menggunakan bantuan software SPSS 19.0 for windows dengan uji statistik Kolmogorov-Smirnov atau ShapiroWilk menggunakan taraf signifikansi 5\%. Hipotesis yang digunakan pada uji normalitas adalah sebagai berikut :

$\mathrm{H}_{0}=$ Data pretest kelas kontrol dan kelas eksperimen berdistribusi normal.

$\mathrm{H}_{1}=$ Data pretest kelas kontrol dan kelas eksperimen berdistribusi tidak normal Kriteria pengujiannya adalah sebagai berikut.

Jika Sig. $\geq 0,05$ maka diterima.

Jika Sig. $<0,05$ maka ditolak.

Jika kedua data berdistribusi normal maka dilanjutkan dengan uji homogenitas varians. Jika salah satu atau kedua data yang dianalisis berdistribusi tidak normal maka tidak dilakukan uji homogenitas varians melainkan dilakukan uji statistik nonparametrik yaitu uji Mann-Whitney. Beikut hasil uji normalitas tersaji pada tabel 6. 
Tabel 6. Tests of Normality

\begin{tabular}{|l|l|c|c|c|c|c|c|}
\hline \multicolumn{2}{|c|}{} & \multicolumn{2}{|c|}{ Kolmogorov-Smirnov } & \multicolumn{3}{c|}{ Shapiro-Wilk } \\
\cline { 3 - 8 } \multicolumn{2}{|c|}{ Data Pretes } & $\begin{array}{c}\text { Statisti } \\
\text { c }\end{array}$ & df & Sig & $\begin{array}{c}\text { Statisti } \\
\text { c }\end{array}$ & df & Sig \\
\hline $\begin{array}{l}\text { VAR0000 } \\
1\end{array}$ & $\begin{array}{l}\text { eksperime } \\
\text { n }\end{array}$ & 063 & 253 & 016 & 964 & 253 & 000 \\
\cline { 2 - 8 } & kontrol & 115 & 251 & 000 & 949 & 251 & 000 \\
\hline
\end{tabular}

a Lilliefors Significance Correction

Dari tabel uji normalitas di atas diperoleh nilai signifikansi skor pretest dengan menggunakan uji Kolmogorov-Smirnov untuk kelas eksperimen sebesar 0,016 dan kelas kontrol sebesar sebesar 0,000, pada taraf signifikansi $\alpha=0,05$. Sedangkan jika diuji dengan uji Shapiro-Wilk maka didapat nilai signifikansi kelas eksperimen sebesar 0,000 dan kelas kontrol sebesar 0,000. Oleh karena nilai signifikansi untuk masingmasing kelas kontrol dan eksperimen lebih kecil dari $\alpha=0,05$, maka $\mathrm{H}_{1}$ yang diterima dan $\mathrm{H}_{0}$ ditolak, dengan kata lain data pretest kelas kontrol dan kelas eksperimen berdistribusi tidak normal, kecuali kelas eksperimen sebesar 0,016 lebih besar dari $\alpha=$ 0,05 yang berarti data tersebut berdistribusi normal.

\section{b. Uji Homogenitas}

Dalam penghitungan uji homogenitas bisa menggunakan bantuan software SPSS 16 for windows dengan menggunakan taraf signifikansi 5\%. Hipotesis yang digunakan pada uji homogenitas adalah sebagai berikut :

$\mathrm{H}_{0}=$ Data pretest kelas kontrol dan kelas eksperimen homogen

$\mathrm{H}_{1}=$ Data pretest kelas kontrol dan kelas eksperimen tidak homogen

Kriteria pengujiannya adalah sebagai berikut.

Jika Sig. $\geq 0,05$ maka $\mathrm{H}_{0}$ diterima.

Jika Sig. < 0,05 maka $\mathrm{H}_{0}$ ditolak.

Hasil uji homogenitas tersaji pada tabel 7.

Tabel 7. Uji homogenitas

\begin{tabular}{|c|c|c|c|}
\hline Levene Statistic & df1 & df2 & Sig. \\
\hline 15.089 & 1 & 504 & 000 \\
\hline
\end{tabular}

Dari tabel uji homogenitas data pretes di atas diperoleh hasil dari uji Levene Statistic skor pretest untuk kelas kontrol dan eksperimen sebesar 0,000, pada taraf signifikansi $\alpha=0.05$. Maka berdasarkan hiipotesis yang digunakan untuk uji homogenitas ini $\mathrm{H}_{1}$ yang diterima dan $\mathrm{H}_{0}$ ditolak, dengan kata lain data pretest kelas kontrol dan kelas eksperimen tidak homogen. Dari hasil di atas dapat terlihat bahwa data skor pretes kelompok ekperimen dan kelompok kontrol berasal dari populasi yang tidak berdistribusi normal dan tidak homogen, maka uji hipotesis yang digunakan adalah uji Mann-Whitney.

\section{c. Uji Hipotesis Penelitian}

Dalam menghitung uji hipotesis penelitian dengan menggunakan uji MannWhitney, sebelumnya dipaparkan hipotesis terlebih dahulu. Hipotesis penelitian dalam penelitian self-instruction training untuk meningkatkan resiliensi Peserta Didik yang akan diuji yakni sebagai berikut:

Ho $: \mu 1=\mu 2$

$\mathrm{H} 1: \mu 1>\mu 2$ 
Keterangan:

$\mu 1=$ rata-rata peningkatan resiliensi kelompok eksperimen.

$\mu 2=$ rata-rata peningkatan resiliensi kelompok kontrol.

Uji Mann-Whitney digunakan untuk mengetahui ada atau tidaknya perbedaan yang signifikan (meyakinkan) dari rerata gain pre tes dan pos tes resiliensi Peserta Didik kelas eksperimen dan kelas kontrol. Uji Mann-Whitney dihitung dengan menggunakan program SPSS 19. Hasil perhitungan disajikan pada tabel 8 .

Tabel 8. Hasil Uji Mann-Whitney Skor Pretes dan Postes Kelas Eksperimen dan Kelas Kontrol

\begin{tabular}{|l|r|}
\hline & skor \\
\hline Mann-Whitney U & 22603,000 \\
\hline Wilcoxon W & 54734,000 \\
\hline Z & $-5,718$ \\
\hline Asymp. Sig. (2-tailed) &, 000 \\
\hline
\end{tabular}

Dari Tabel di atas terlihat bahwa nilai signifikansi (sig.) sebesar 0.000 lebih kecil dari $\alpha=0.05$, sehingga kesimpulan statistik yang diambil adalah $\mathrm{H} 1$ diterima, artinya self-instruction training efektif untuk meningkatkan resiliensi Peserta Didik.

\section{Pembahasan}

\section{Profil Resiliensi Peserta Didik}

Data hasil penelitian mengindikasikan profil resiliensi Peserta Didik SMK Negeri 1 Pemalang kelas XI. TKJ 1 dan 2 yakni bahwa mayoritas Peserta Didik memiliki kecenderungan resiliensi pada tingkat sedang atau termasuk dalam kategori cukup resilien sebanyak 45 Peserta Didik (62,5\%). Hal ini menunjukkan bahwa tingkat kecenderungan resiliensi Peserta Didik sampel penelitian belum mencapai tahap optimal dalam arti masih perlu ditingkatkan, ditambah lagi fakta bahwa jumlah Peserta Didik sampel penelitian yang memiliki kecenderungan resiliensi pada tingkat rendah atau termasuk dalam kategori kurang resilien sejumlah 19 Peserta Didik (26,39\%) dapat dikatakan masih cukup banyak.

Castro, Johnson \& Smith, (2011) mengemukakan, bahwa semua individu telah memiliki modal yang cukup untuk mengembangkan resiliensi, modal tersebut berupa kapasitas adaptasi yang sifatnya alamiah dan instingtif oleh karena itu individu hanya tinggal membuka lebar kapasitas tersebut untuk meningkatkan kemampuan merespon secara positif dampak negatif dari pengalaman adversitas. Hal tersebut diprediksi menjadi salah satu alasan mengapa dalam banyak studi lainnya tingkatan resiliensi yang dominan ditunjukkan oleh populasi penelitian atau subjek penelitian adalah resiliensi dalam tingkatan sedang, atau rata-rata (average), atau moderat, yakni karena individu memiliki suatu kapasitas alamiah dalam diri mereka untuk merespon terhadap berbagai pengalaman yang sifatnya menyakitkan, menekan, dan mengancam.

Berbagai kecenderungan yang memperkokoh hasil penelitian terkait tingkatan resiliensi Peserta Didik yang mayoritas berada pada kategori sedang atau moderat tidak menjadikan upaya untuk meningkatkan resiliensi Peserta Didik berkurang urgensinya. Berbagai fakta menegaskan bahwa pengembangan resiliensi sangat diperlukan oleh Peserta Didik sebagai kompetensi menghadapi transisi menuju masa dewasa yang sarat tantangan dan tekanan, serta untuk memperoleh status kesehatan mental yang sehat dan terpelihara sepanjang masa kehidupan selanjutnya (Goldstein , 2005:29).

Pertimbangan lain mengenai kemungkinan bahwa dampak dari adversitas tidak muncul secara segera akan tetapi dapat muncul sekian lama kemudian di masa depan, 
dibuktikan dengan adversitas awal yang terjadi pada Peserta Didik yang mengalami pengabaian atau kekerasan oleh orang tua nya dapat berdampak pada kemampuan Peserta Didik tersebut untuk membangun keluarga yang fungsional dimasa dewasa (Anesty, 2012:163). Peserta Didik yang mengalami adversitas khususnya yang bersifat traumatik dan bertahan lama, cenderung rentan terhadap simptom distress yang dapat mereka alami dimasa depan, karena alasan tersebut maka kemampuan resiliensi yang sifatnya berkelanjutan sangat tepat dipertimbangkan dalam menghadapi kerentanan yang berlanjut pula serta untuk tanggap terhadap berbagai dinamika perubahan keberfungsian Peserta Didik sepanjang waktu (Anesty, 2012:165). Hal ini terlihat pada Peserta Didik Kelas XI. TKJ 1 dan 2 SMK Negeri 1 Pemalang mengalami kejenuhan, mudah capai, malas mengerjakan tugas dan lebih mudah mengalami stres

\section{Penerapan Teknik Bibliocounseling untuk Meningkatkan Resiliensi Peserta Didik}

Dalam proses biblioterapi, konselor dan subjek mengidentifikasi berbagai alternatif solusi atau tindakan yang ditunjukkan oleh tokoh dalam cerita novel dan menginternalisasinya ke dalam masalah yang dialami subjek. Selanjutnya, konselor dan subjek mendiskusikan masalah yang dialami subjek dengan penuh keterbukaan. Topik lain yang didiskusikan dalam konseling kelompok adalah keterampilan menyelesaikan masalah sebagaimana ditunjukkan oleh tokoh dalam cerita. Sesi terakhir merupakan sesi mengembangkan konsep diri partisipan dengan mendiskusikan bagaimana tokoh dalam novel mengembangkan diri setelah kemalangan yang dialaminya (Maich \& Kean, 2004).

Pemecahan masalah yang ada dalam cerita dapat mengubah cara Peserta Didik berinteraksi dan memperlakukan orang lain. Dengan mengidentifikasi karakter dalam novel, Peserta Didik memahami bahwa mereka tidaklah sendirian dalam menghadapi masalah. Dalam sesi konseling, konseli mengembangkan pemahaman terhadap masalah yang dialami oleh tokoh dalam cerita, mengidentifikasi berbagai akar permasalahan yang muncul dan mengidentifikasi berbagai kemungkinan dampak yang akan muncul dari masalah tersebut.

Penerapan teknik biblioterapi akan efektif dalam meningkatkan resiliensi Peserta Didik SMK Negeri 1 Pemalang dipengaruhi oleh beberapa faktor, di antaranya oleh minat baca dan motivasi subjek untuk berubah. Subjek yang memiliki minat baca tinggi akan dengan seksama memahami setiap bagian bacaan dan melibatkan faktor emosi dan kognisi ketika membacanya. Sebagai contoh, pembaca membayangkan dirinya menjadi tokoh dalam cerita tersebut dalam menghadapi situasi sulit. Subjek juga dapat membayangkan alternatif solusi yang paling sesuai dengan masalah yang dihadapinya. Individu yang rasional dan reflektif akan mengalami proses biblioterapi yang efektif (Purwanto, 2015).

\section{KESIMPULAN}

Teknik bibliocounseling merupakan kegiatan terapi membaca menggunakan media buku atau literatur tertentu. Pada satu sisi, dapat pula penggunaan film, video, gambar hidup sebagai media untuk mengembangkan sikap dan mengentaskan permasalahan yang dihadapi oleh individu. Dengan berbasis buku spiritual dan bibiografi pengusaha muda Indonesia sukses yang memiliki aspek religius dan jiwa entrepeneur yang kuat, teknik bibliocounseling akan lebih efektif dalam upaya meningkatkan resiliensi individu.

Pada penelitian ini membuktikan bahwa terdapat peningkatan resiliensi Peserta Didik atau dengan kata lain model bimbingan kelompok dengan teknik bibliocounseling efektif untuk meningkatkan resiliensi Peserta Didik. Dengan demikian, model bimbingan kelompok yang diterapkan memberikan kontribusi positif terhadap pelayanan bimbingan dan konseling di sekolah.

Bagi guru bimbingan konseling di sekolah atau konselor dapat disarankan agar layanan bimbingan kelompok dengan teknik bibliocounseling dapat diprogramkan secara periodik 
terutama terhadap Peserta Didik yang skala resiliensi masuk pada kategori rendah dan kurang. Saran untuk penelitian lanjut adalah hendaknya diaplikasikan suatu strategi research lanjutan yang bertujuan untuk mempercepat peningkatan resiliensi. Selain itu, penggunaan teknik bibliocounseling tidak hanya dilakukan di sekolah, sehingga bisa dipastikan secara lebih objektif apakah model layanan bimbingan kelompok dengan teknik bibliocounseling juga layak diberikan kepada individu lainnya pada masa/usia atau status yang berbeda.

Penelitian di masa depan dapat dilakukan untuk menentukan apakah teknik bibliocounseling yang digunakan dalam penelitian ini dapat diadaptasi dan atau dikembangkan dengan metode atau versi yang beragam lainnya. Keterbatasan model, istilahistilah asing (bibliocounseling) yang sulit dipahami, materials literature yang belum banyak dijual di pasaran, panjangnya durasi bimbingan kelompok dengan teknik bibliocounseling dan ukuran kelompok harus dipertimbangkan.

\section{DAFTAR PUSTAKA}

Anesty, E. (2012). Konseling Rasional Emotif Behavioral Untuk meningkatkan Resiliensi Remaja. Tesis pada Sekolah Pascasarjana UPI Bandung: Tidak diterbitkan.

Campbell, D. T. \& Stanley, J. C. (1963). Experimental and Quasi-Experimental Designs for Research. Boston: Houghton Mifflin Company.

Castro, V., Johnson, M. B. \& Smith, R. (2011). Self-Reported Resilient Behaviors of Seventh and Eighth Grade Students Enrolled in an Emotional Intelligence Based Program. (Lecture Paper). Universitas of Texas Pan American.

Challen, A.R., Machin, S. J., \& Gilham, J. E. (2014). The UK resilience program a schollbased universal nonrandomized pragramatic controlled trial. Journal of Consulting and Clinical Psychology, Volume 84, Nomer. 1, Hlm. 75-89.

Creswell, J.W. (2007). Qualitative inquiry \& research design choosing among five approaches. Second Edition. Sage Publications - California.

Goldstein, S., \& Brooks, R. B. (2005). Handbook of Resilience in Children. New York, USA: Springer Science and Business Media, Inc.

Hariyadi, S. 2014. Pengembangan Model Layanan Bimbingan Kelompok dengan Teknik Bibliocounseling Berbasis Cerita Rakyat untuk Mengembangkan Kecerdasan Intrapersonal Peserta Didik SMP Negeri 1 Gunem. Jurnal Bimbingan Konseling, 3(2).

Hasfera, D. (2018). Bibliotheraphy: Layanan bimbingan konseling di perpustakaan. Shaut Al Maktabah: Jurnal Perpustakaan, Arsip dan Dokumentasi, 10(1), 39-62.

Isaacson, B. (2010). Characteristics and Enhancement of Resiliency in Young People.http://www.uwstout.ede/lib/thesis/2002/2002 isaacsonb.pdf.

Klohnen, E.C. (1996). Conseptual analysis and measurement of the construct of ego resilience. Journal of Personality and Social Psychology,70 (5), 1067-1079

Lucas, C. V., \& Soares, L. 2013. Bibliotherapy: a Tool to Promote Children's Psychological wellbeing. Journal of Poetry Therapy, 26(3): 137-147.

Maich, K., \& Kean, S. (2004). Read Two Books and Write Me in the Morning! Bibliotherapy for Social Emotional Intervention in the Inclusive Classroom. TEACHING Exceptional Children Plus, 1(2).

Montgomery, P., Maunders, K. (2015). The Effectiveness of Creative Bibliotherapy for Internalizing, Externalizing, and Prosocial Behaviors in Children: A Systematic Review. Children and Youth Services Review, 55, 37-47.

Purwanto, E. (2015). Pengaruh Bibliotherapy terhadap Psychological Well-being Perempuan Lajang. CALYPTRA, 4(1), 1-26.

Schoon, I. (2006). Risk and Resilience, Adaptations in Changing Times. New York : Cambridge University Press

Sholih, Rochani , Deasy Yunika Khairun, Ibrahim Al Hakim. (2017). Meningkatkan Resiliensi Remaja melalui Bibliocounseling. Jurnal Prodi Bimbingan dan Konseling Fakultas Keguruan dan Ilmu Pendidikan UNTIRTA. 
Sugiyono. (2012). Metode Penelitian Pendidikan. Bandung : CV. Alfabeta.

Tugade, M. M., \& Fredrickson, L. B. (2004). Resilient individuals use positive emotions to bounce back from negative emotions experiences. Journal of Personality and Social Psychology, 86 (2), 320-333 